\title{
ANALISIS KEMAMPUAN BERPIKIR KRITIS SISWA SMA PADA MATERI KOPERASI
}

\author{
${ }^{1}$ Wahyu Mustajab, ${ }^{2}$ Syamsul Hadi Senen, ${ }^{3}$ kaputera Waspada \\ 1, 2, 3 Universitas Pendidikan Indonesia \\ Wahyumustajab821@student.upi.edu
}

\begin{abstract}
Critical thinking is a way of thinking by knowing and analyzing things to get a solution. Critical thinking skills applied in students to learn to solve problems / problems. This study aims to determine the ability of critical thinking of high school students in cooperative material in class $X$. The method used in this research is descriptive method. Subjects in this study are high school students of class $X$ in Kabupaten Ciamis. The sample used is 93 students, consisting of 3 classes of 32 students from IIS 1, 27 students from IIS 2 and 34 students from IIS 3. The research instrument used is about knowledge about cooperative material which amounts to 25 choices double with four alternative answer choices, the questions used are arranged according to critical thinking indicator with C4-C6 cognitive level. Data analysis used is quantitative descriptive analysis. the average of students' critical thinking early ability is $49.35 \%$ (Low) or in the low category. The low initial ability of critical thinking makes the researcher assume that students are not used to get the problem with cognitive level of C4-C6 on cooperative material. So it is necessary to do better coaching to improve students' critical thinking skills. In addition, students are also required or accustomed in solving problems with high levels of cognitive C4-C6 or cognitive level.
\end{abstract}

Keyword: Cognitive Level, Critical Thinking

\begin{abstract}
ABSTRAK
Berpikir kritis merupakan cara berpikir dengan mengenal dan menganalisis suatu hal untuk mendapatkan solusi. Kemampuan berpikir kritis diterapkan di siswa untuk belajar memecahkan masalah/soal. Penelitian ini bertujuan untuk mengetahui kemampuan berpikir kritis siswa SMA pada materi koperasi di kelas $X$. Metode yang digunakan dalam penelitian ini yaitu metode deskriptif. Subjek dalam penelitian ini yaitu siswa SMA kelas $X$ di Kabupaten Ciamis. Sampel yang digunakan yaitu berjumlah 93 siswa, yang terdiri dari 3 kelas yaitu 32 siswa berasal dari IIS 1, 27 siswa berasal dari IIS 2 dan 34 siswa berasal dari IIS 3. Instrumen penelitian yang digunakan yaitu soal pengetahuan tentang materi koperasi yang berjumlah 25 soal pilihan ganda dengan empat pilihan alternatif jawaban, soal yang digunakan disusun menurut indikator berpikir kritis dengan tingkat kognitif C4-C6. Analisis data yang digunakan yaitu analisis deskriptif kuantitatif. rata-rata kemampuan awal berpikir kritis siswa yaitu 49,35\% (Rendah) atau berada pada kategori rendah. Rendahnya kemampuan awal berpikir kritis siswa membuat peneliti berasumsi bahwa siswa belum terbiasa mendapatkan soal dengan tingkat kognitif C4-C6 pada materi koperasi. Sehingga perlu dilakukannya pembinaan yang lebih baik untuk meningkatkan kemampuan berpikir kritis siswa. Selain itu, siswa juga diharuskan atau dibiasakan dalam menyelesaikan soalsoal dengan tingkat kognitif C4-C6 atau kognitif tingkat tinggi.

Kata kunci: Tingkat Kognitif, Berpikir Kritis
\end{abstract}




\section{PENDAHULUAN}

Kemampuan berpikir tingkat tinggi siswa di indonesia masih tergolong rendah. Hal tersebut didasarkan pada hasil studi lembaga internasional dari Program for International Student Assesment (PISA), tahun 2012 bertema "Evaluating School Systems to Improve Education" yaitu menduduki peringkat ke 64 dari 65 negara. Berpijak pada data empiris tersebut, upaya peningkatan kualitas proses pembelajaran hendaknya dilakukan sedini mungkin dengan meninggalkan kebiasaan proses belajar klasikal, yang cenderung memfasilitasi pemahaman siswa. Pentingnya kemampuan berpikir siswa dalam proses pembelajaran sangat mempengaruhi perkembangan kognitif, afektif dan pisikomotorik siswa dalam bersikap, mengambil keputusan, dan cara-cara memecahkan masalah baik secara sendiri maupun secara kelompok.

Kemampuan berpikir kritis harus dimiliki oleh siswa. Berpikir kritis merupakan keterampilan kognitif yang dapat dikembangkan melalui proses pembelajaran yang terencana (Duron, Limbach, \& Waugh, 2006). Ennis (1989) berpendapat bahwa berpikir kritis merupakan berpikir secara beralasan dan reflektif dengan menekankan pada pembuatan keputusan tentang apa yang harus dipercayai atau dilakukan.

Untuk melihat kemampuan berpikir kritis siswa, peneliti melakukan penelitian kemampuan awal terlebih dahulu. Penelitian kemampuan awal bertujuan melihat sejauh mana kemampuan awal berpikir kritis siswa sebelum dilakukan perlakuan. Hal tersebut sesuai dengan pendapat Sumantri (2015) yang menyatakan bahwa kemampuan awal siswa merupakan kemampuan yang telah dipunyai oleh siswa sebelum ia mengikuti pembelajaran yang akan diberikan.

Kemampuan awal adalah pengetahuan dan keterampilan yang telah dimiliki siswa sehingga mereka dapat mengikuti pelajaran dengan baik (Suparman dalam Wahyono, 2013). Selain itu, Winkel dalam Wahyono (2013) mengemukakan bahwa kemampuan awal merupakan jembatan untuk menuju pada kemampuan final, dimana pada setiap proses pembelajaran mempunyai titik tolaknya sendiri atau berpangkal pada kemampuan awal siswa tertentu untuk dikembangkan menjadi kemampuan baru, setiap apa yang menjadi tujuan dalam proses pembelajaran.

\section{LANDASAN TEORI}

1. Pengertian berpikir kritis

Socrates telah membicarakan tentang berpikir kritis sejak 2.000 tahun yang lalu. Akan tetapi, John Dewey seorang filsuf Amerika, psikolog dan pendidik, secara luas dianggap sebagai "bapak" dari konsep berpikir kritis modern (Fisher, 2001). Berpikir kritis merupakan keterampilan kognitif yang dapat dikembangkan melalui proses pembelajaran yang terencana (Duron, Limbach, \& Waugh, 2006).

Ennis (1989) berpendapat bahwa berpikir kritis merupakan berpikir secara beralasan dan reflektif dengan menekankan pada pembuatan keputusan tentang apa yang harus dipercayai atau dilakukan. Berpikir kritis dapat digunakan dalam berpendapat untuk (diri sendiri atau orang lain) dengan tujuan untuk mencari apa yang harus dipercaya atau dilakukan (Budmen, 1967). Selain itu, Scriven dan Paul (1987) dalam Clark \& Paulsen (2016) menyatakan bahwa pemikiran kritis melibatkan analisis informasi yang dikumpulkan melalui refleksi.

2. Indikator kemampuan berpikir kritis

Ada lima ranah keahlian dengan berbagai indikatornya mengenai berpikir kritis yaitu sebagai berikut:

a. Penafsiran. Memahami dan mengungkapkan arti atau pentingnya perbedaan pengalaman, situasi, data, kejadian, penilaian, penemuan, keyakinan aturan, prosedur atau kriteria.

b. Analisis. Mengindentifikasi kecenderungan dan kesimpulan actual hubungan antara pernyataan. Pertanyaan, konsep, deskripsi atau bentuk lain representasi yang 
dimaksudkan untuk menyatakan keyakinan, penilaian, pengalaman, pemikiran, informasi dan pendapat.

c. Evaluasi. Untuk menilai kredibilitas pernyataan atau representasi lain yang penting atau penggambaran persepsi orang, pengalaman, situasi, penilaian kenyakinan, atau pendapat dan untuk menilai kekuatan logis, kesimpulan actual atau kecenderungan hubungan antar pernyataan, deskripsi, pertanyaan atau bentuk representasi lainya.

d. Kesimpulan. Untuk menganalisis dan menyakini elemen yang dibutuhkan untuk menarik kesimpulan yang masuk akal, untuk membentuk hipotesis dan perkiraan, untuk memperhitungkan informasi relevan dan memperhitungkan konsekuensi yang mengalir dari data, pernyataan, prinsip, bukti, penilaian, keyakinan, pendapat, konsep, deskripsi, pertanyaan, atau bentuk lain representasi.

e. Penjelasan. Untuk menyatakan hasil pemikiran, untuk mengesahkan pemikiran dalam kerangka bukti, konsep, metode, kriteria dan pertimbangan kontekstual yang menjadi dasar pemikiran seseorang dan untuk menyajikan pemikiran orang dalam bentuk argument yang kuat. (Jean, 2003)

Menurut Ennis (Costa, 1988) indikator kemampuan berpikir kritis dibagi menjadi lima kelompok yaitu: (1) memberikan penjelasan sederhana (elementary clarification), (2) membangun keterampilan dasar (basic support), (3) membuat kesimpulan (inferring), (4) membuat penjelasan lebih lanjut (advanced clarification), dan (5) mengatur strategi dan taktik (strategies and tactics).

Indikator berpikir kritis harus dipahami oleh guru dan praktisi pendidikan. Mengembangkan kemampuan berpikir kritis melibatkan kognitif siswa untuk menganalisis dan mengevaluasi gagasan atau argument berdasarkan informasi dan sumber lain yang mendukung, sehingga hal ini memungkinkan siswa dapat menciptakan teori sendiri dari penemuan yang diperolehnya.

\section{Langkah mengembangkan berpikir kritis}

Menurut Sihotang, dkk (2012) langkah-langkah yang perlu diperhatikan dalam mengembangkan kemampuan berpikir kritis adalah :

a. Mengenali masalah, pengenalan terhadap masalah merupakan tahap pertama untuk menunjukan berpikir kritis, dimana seseorang yang berpikir kritis harus mengidentifikasi persoalan terlebih dahulu sebelum menari kesimpulan.

b. Menemukan cara-cara yang dapat dipakai untuk menangani masalah, pengetahuan yang lebih luas dan usaha kreatif untuk mencarinya adalah salah satu yang penting untuk mendukung berpikir kritis.

c. Mengumpulkan dan menyusun informasi yang diperlukan untuk menyelesaikan masalah, seperti pengetahuan yang luas diperlukan dalam mengatasi masalah, demikian halnya informasi yang penting terkait dengan persoalan perlu di kumpulkan. Informasi yang cukup membuat kita mampu menilai sesuatu secara tepat dan akurat.

d. Mengenal asumsi-asumsi dan nilai-nilai yang tidak dinyatakan, artinya seseorang berpikir kritis perlu mengetahui maksud atau gagasan-gagasan di balik sesuatu yang tidak dinyatakan oleh orang lain, disinilah dituntut seseorang mampu menganalisis yang tajam.

e. Menggunakan bahasa yang tepat, jelas, dan khas dalam membicarakan suatu persoalan atau suatu hal yang diterimanya. Istilah-istilah yang kita gunakan dalam menanggapi persoalan haruslah berkaitan dengan topic yang dibahas.

f. Mengevaluasi data dan menilai fakta serta pernyataan-pernyataan.

g. Mencermati adanya hubungan logis antara masalah-masalah dengan jawaban-jawaban yang diberikan.

h. Menarik kesimpulan-kesimpulan atau pendapat tentang isu atau persoalan yang sedang dibicarakan. 


\section{Keuntungan berpikir kritis}

keuntungan dari berpikir kritis yaitu peserta didik mampu mengubah pemikirannya menjadi lebih baik lagi, peserta didik mampu mengeluarkan beberapa ide-ide atau gagasan dalam memecahkan suatu masalah dengan jalan berdiskusi dengan teman sebaya atau dengan kata lain peserta didik mampu mengkostruk pengetahuannya.

\section{METODE}

Metode penelitian yang digunakan dalam penelitian ini yaitu metode deskriptif. Metode deskriptif bertujuan mendeskripsikan kemampuan awal berfikir kritis siswa SMA pada materi koperasi. Subjek dalam penelitian ini yaitu siswa SMA kelas $X$ di Kabupaten Ciamis. Sampel yang digunakan yaitu berjumlah 93 siswa, yang terdiri dari 3 kelas yaitu 32 siswa berasal dari IIS 1, 27 siswa berasal dari IIS 2 dan 34 siswa berasal dari IIS 3.

Instrumen yang digunakan sudah valid dengan menggunakan SPSS 22. Instrumen penelitian yang digunakan yaitu soal pengetahuan koperasi yang berjumlah 25 soal pilihan ganda dengan empat pilihan alternatif jawaban. Analisis data yang digunakan yaitu analisis deskriptif kuantitatif. Rata-rata kemampuan awal berpikir kritis siswa dianalisis dengan kriteria yang tercantum pada Tabel 1.

Tabel 1. Kriteria rata-rata kemampuan awal berpikir kritis siswa

\begin{tabular}{|c|c|}
\hline $86-100$ & Sangat tinggi \\
\hline $71-85$ & Tinggi \\
\hline $56-70$ & Sedang \\
\hline $41-55$ & Rendah \\
\hline$<40$ & Sangat rendah \\
\hline
\end{tabular}

(adaptasi Agip et al., 2009)

\section{HASIL DAN PEMBAHASAN}

Pengetahuan awal berpikir kritis siswa adalah pengetahuan yang dimiliki siswa sebelum proses pembelajaran berlangsung. Pengetahuan awal berpikir kritis siswa dalam penelitian ini berdasarkan rata-rata dari nilai tes pengetahuan siswa pada materi koperasi. Rata-rata kemampuan awal berpikir kritis siswa pada materi koperasi dari tiga kelas dapat dilihat pada Tabel 2.

Tabel 2. Rata-rata kemampuan awal berpikir kritis siswa

\begin{tabular}{|l|l|l|l|l|}
\hline Kelas & $\begin{array}{c}\mathbf{n} \\
\text { siswa }\end{array}$ & $\begin{array}{c}\text { Nilai } \\
\text { min }\end{array}$ & $\begin{array}{c}\text { Nilai } \\
\text { maks }\end{array}$ & $\begin{array}{c}\text { Rata- } \\
\text { rata }\end{array}$ \\
\hline IIS 1 & 32 & 30 & 78 & 48,75 \\
\hline IIS 2 & 27 & 26 & 62 & 42,30 \\
\hline IIS 3 & 34 & 34 & 74 & 55,53 \\
\hline Total & $\mathbf{9 3}$ & $\mathbf{2 6}$ & $\mathbf{7 8}$ & $\mathbf{4 9 , 3 5}$ \\
\hline
\end{tabular}

Berdasarkan Tabel 2, rata-rata kemampuan awal berpikir kritis siswa yaitu 49,35 atau berada pada kategori rendah. Rata-rata tersebut didapatkan dari hasil kemampuan awal berpikir kritis siswa yang didapatkan oleh IIS 1 sebesar 48,75, IIS 2 sebesar 42,30 dan IIS 3 sebesar 55,53. Rata-rata kemampuan awal berpikir kritis siswa dari ketiga kelas tersebut masih berada pada kategori rendah.

Rendahnya kemampuan awal berpikir kritis siswa membuat peneliti berasumsi bahwa siswa belum terbiasa mendapatkan soal dengan tingkat kognitif C4-C6 pada materi koperasi. Sehingga perlu dilakukannya pembinaan yang lebih baik untuk meningkatkan kemampuan berpikir kritis siswa. Selain itu, siswa juga perlu dibiasakan dalam menyelesaikan soal-soal dengan tingkat kognitif C4-C6.

Kemampuan awal berpikir kritis sangat penting. Menurut Winkel dalam Wahyono (2013), kemampuan awal diibaratkan sebagai jembatan menuju kemampuan final. 
Sehingga dapat diasumsikan bahwa kemampuan awal bukan hal yang dapat dipandang sebelah mana. Kemampuan awal siswa akan membawa siswa menuju kemampuan selanjutnya. Hal tersebut sesuai dengan pendapat Razak (2017) yang menyatakan bahwa, kemampuan awal yang baik akan memiliki kemampuan berpikir kritis yang baik pula.

\section{KESIMPULAN}

Berdasarkan hasil analisis data dan pembahasan maka dapat ditarik kesimpulan sebagai berikut:

Kemampuan awal berpikir kritis siswa mendapatkan hasil sebesar 49,35 atau berada pada kategori rendah.

\section{DAFTAR PUSTAKA}

Buku:

Agip, Z. dkk. (2009). Penelitian Tindakan Kelas untuk Guru SD, SLB dan TK. Bandung: Yrama Widya

Sihotang, Rima, Molan, Ujan dan Ristyantoro.(2012). Critical Thingking Membangun Pemikiran Logis. Jakarta : PT. Pustaka Sinar Harapan

Sumantri, M. S. (2015) Strategi Pembelajaran Teori dan Praktik di Tingkat Pendidikan Jurnal: Dasar. Jakarta: Raja Grafindo Persada

Budmen, K. O. (1967). "What do you think, teacher?" .... Critical thinking a partnership in learning. Peabody Journal of Education, 45 (1), 2-5. https://doi.org/10.1080/01619566709537475

Clark, T. K., \& Paulsen, T. H. (2016). Analyzing Student Teacher Critical Thinking through Blogs in an Electronic Community of Practice, 57 (2), 75-92. https://doi.org/10.5032/jae.2016.02075

Costa, P. T., \& McCrae, R. R. (1988). Personality in adulthood: a six-year longitudinal study of self-reports and spouse ratings on the NEO Personality Inventory. Journal of Personality and Social Psychology, 54 (5), 853-863. https://doi.org/10.1037/00223514.54.5.853

Duron, R., Limbach, B., \& Waugh, W. (2006). Critical Thinking Framework For Any Discipline. International Journal of Teaching and Learning in Higher Education, 17 (2), 160-166. https://doi.org/10.1016/j.nepr.2006.09.004

Ennis, R. H. (1989). Critical thinking and subject specificity: Clarification and needed research. Educational Researcher, 18 (3), 4-10. https://doi.org/10.3102/0013189X018003004

Fisher, A. (2001). Critical Thinking. An Introduction. Library, 44 (13), 17. https://doi.org/10.2307/2019787

Jean, M. (2003). Critical Thinking and Creativity an Overview and Comparison of The Theories. Journal Critical Thinking \& Creativity. Desember 2003.

\section{Review:}

Nurhida Yati (2014) Analisis kemampuan berpikir kritis sisiwa dalam memecahkan soal pada materi virus di SMA Negeri 3 Kota Jambi (Diakses 7 April 2018) 